\title{
REVIEW
}

\section{PLANT PHYSIOLOGICAL ECOLOGY AND THE GLOBAL CHANGES}

\author{
Ecofisiologia vegetal e as mudanças globais \\ João Paulo Rodrigues Alves Delfino Barbosa ${ }^{1}$, Serge Rambal' ${ }^{2}$, Angela Maria Soares ${ }^{3}$, \\ Florent Mouillot ${ }^{4}$, Joana Messias Pereira Nogueira ${ }^{3}$, Giordane Augusto Martins ${ }^{5}$
}

\begin{abstract}
The global changes are marked by alteration on the normal patterns of important biochemical and biophysical processes of the Earth. However, the real effects as well as the feedbacks of the global changes over vegetation are still unclear. Part of this uncertainty can be attributed to the inattention of stakeholders and scientists towards vegetation and its complex interrelations with the environment, which drive plant physiological processes in different space-time scales. Notwithstanding, some key subjects of the global changes could be better elucidated with a more plant physiological ecology approach. We discuss some issues related to this topic, going through some limitations of approaching vegetation as a static component of the biosphere as the other sub-systems of the Earth-system change. With this perspective, this review is an initial reflection towards the assessment of the role and place of vegetation structure and function in the global changes context. We reviewed the Earth-system and global changes terminology; attempted to illustrate key plant physiological ecology researches themes in the global changes context; consider approaching plants as complex systems in order to adequately quantify systems characteristics as sensibility, homeostasis, and vulnerability. Moreover, we propose insights that would allow vegetation studies and scaling procedures in the context of the Earth-system. We hope this review will assist researchers on their strategy to identify, understand and anticipate the potential effects of global changes over the most vulnerable vegetation processes from the leaf to the global levels.
\end{abstract}

Index terms: Landscape ecology, vegetation modeling, remote sensing, scaling problems, vulnerability.

\section{RESUMO}

As mudanças globais englobam importantes alterações nos padrões normais de processos bioquímicos e biofísicos da Terra. Os reais efeitos e retroalimentações das mudanças globais sobre a vegetação ainda são incertos. Parte das incertezas pode ser atribuída à falta de atenção de cientistas e políticos para a vegetação, enquanto componente do sistema terrestre. Entretanto, algumas questões sobre as mudanças globais poderiam ser mais bem esclarecidas por abordagens mais voltadas à ecofisiologia vegetal. Nesse artigo, alguns pontos relacionados e esses problemas, como as limitações em se abordar a vegetação como um componente estático da atmosfera enquanto outros subsistemas do sistema terrestre são dinâmicos, são discutidos. Dentro dessa perspectiva, essa revisão traz uma reflexão inicial do papel da vegetação, em termos de estrutura e funcionamento, no contexto das mudanças globais. Para isso, foi feita uma revisão das terminologias relacionadas às mudanças globais e ao sistema terrestre, buscou-se ilustrar alguns dos principais temas de pesquisa da ecofisiologia vegetal no contexto das mudanças globais. Foram feitas considerações em relação ao tratamento de plantas como sistemas complexos, o que é importante para o estudo de aspectos relacionados à sensibilidade, estabilidade e vulnerabilidade a variações ambientais. Finalmente, são discutidas alternativas que podem ser utilizadas para incorporar aspectos do funcionamento da vegetação, de forma dinâmica, em estudos de mudanças globais, considerando o desafio de mudança de escalas. Espera-se que essa revisão possa auxiliar pesquisadores subsidiando suas estratégias de identificação e compreensão dos efeitos potenciais das mudanças globais sobre os processos mais vulneráveis da vegetação, da folha ao globo.

Termos para indexação: Ecologia da paisagem, modelagem da vegetação, sensoriamento remoto, problemas de escala, vulnerabilidade.

\section{(Received in march 27, 2012 and approved in april 20, 2012)}

\section{THE EARTH -SYSTEM AND THE GLOBAL CHANGES}

The Earth-system has been defined as the evolving complex system comprising the atmosphere, hydrosphere, lithosphere, cryosphere, biosphere and anthroposphere as sub-systems (RAUPACH; CANADELL, 2010). Although such definition appears simple, it is extensive since it bears all the burden of the intricate physical, chemical and biological relationships among sub-systems and among the multitude of components inside sub-systems. These relationships incorporates to the Earth important attributes of complex systems, as the one of respond smoothly to

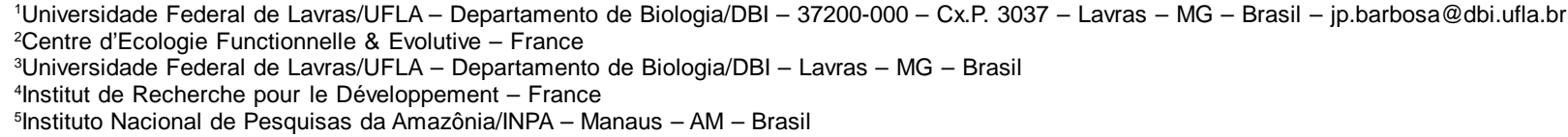


changing pressures, react in a nonlinear, often abrupt, way, and the sensitivity around threshold levels of certain key variables (SOUZA; BUCKERIDGE, 2004; SMITH; WANDEL, 2006; GALLOPÍN, 2006; ROCKSTRÖM et al., 2009). This sensitivity signifies that if these thresholds are crossed, then important processes could shift into a new state, often with deleterious or potentially even disastrous consequences for the entire system (EDELMAN; GALLY, 2001; SOUZA et al., 2005a; ROCKSTRÖM et al., 2009; RAUPACH; CANADELL, 2010).

The sub-system that has been highlighted in recently in the Earth-system science is the anthroposphere. Some researchers defend that the sphere of human societies, cultures, knowledge, economies and built environments have been deeply transforming the Planet in the last century, affecting the normal patterns of variability of Earth's physical, chemical and biological components. The term global changes arise from the magnitude and rate of the alterations caused by the anthroposphere on the Earth (CRUTZEN, 2002; CRUTZEN; STEFFEN, 2003; RAUPACH; CANADELL, 2010).

Those changes are so great that in a moment of the planet's geological time, the period since the industrial revolution is often called the 'Anthropocene' to distinguish it from the preceding Holocene. In the Anthropocene, human activities are significantly modifying the great natural cycles of carbon, water and nutrients, together with climate, biodiversity, land cover and other features of the state and function of the vegetation in comparison with the previous Holocene period (CRUTZEN; STEFFEN, 2003; FOLEY et al., 2003; ROCKSTRÖM et al., 2009; FRIEND, 2010; MALHI, 2012).

There is a generalized tendency of employing the terms global change and climate change as synonyms. Inside the global changes, alterations in the patterns of climate variability are currently the most significant and far-reaching environmental feature facing humanity. Scientists, policymakers, the media and governments from around the world are seeking to understand the nature of the changes that are likely to occur during the 21 st century and beyond, as well as the effects and feedbacks these changes could have on components and sub-systems that underpin the Earth-system (COX et al., 2000; CRAMER et al., 2001; CRUTZEN, 2002; DAVIDSON; ARTAXO, 2004; COATES et al., 2011).

For this reason the climate changes linked to global warming is maybe the most significant element in the global changes. However, one has to consider that the Earthsystem is much more than just the climate. Roughly, it is obligatory to consider that the global changes involve modifications in the patterns of normal variability of the functioning of physical, chemical and biological processes of any component or sub-component of the Earth, including the climate system. In this context, the term global changes covers global warming linked with climate changes, with its causes, effects and feedbacks into the complex and intricate interactions within the Earthsystem.

Besides the climate changes, Rockström et al. (2009) also indicate as critical effects of global changes the rate of biodiversity loss and alterations on the nitrogen and phosphorus cycles. These Earth-system processes are very close related to terrestrial plant functioning and the interplay among them could affect the normal patterns of biochemical and biophysical relationships between vegetation and environment. The real consequences on this subject are considered inconclusive in diverse aspects. However, studies from over one decade have pointed out convincing evidences of new scenarios of land cover and use, vegetations structure, ecosystems services, food production, water availability and regional to global weather variability as a results of the effects of global changes over vegetation (COSTANZA et al., 1997; HURTT et al., 1998; COX et al., 2000; SAXE et al., 2001; WALTHER et al., 2002; FOLEY et al., 2003; HULME, 2005; NIYOGI; XUE, 2006; MENGE; FIELD, 2007; BONAN, 2008; BERRY et al., 2010; JACKSON et al., 2011; MALHI, 2012).

\section{KEY OUTPUTS OF PLANT PHYSIOLOGICAL ECOLOGY IN THE EARTH-SYSTEM CONTEXT}

Considering that we already experiment a new geological era marked by the cross of the stability threshold of fundamental Earth-system processes (ROCKSTRÖM et al., 2009), it is evident that plants are modifying their physiological and ecological processes in order to adapt and survive to the new environmental scenarios imposed by the global changes (WALTHER et al., 2002; FOLEY et al., 2003; BONAN, 2008; BERRY et al., 2010; COATES et al., 2011). This way, the global changes can be considered the principal threat to vegetation functioning, with potential negative feedbacks over the other components of the biosphere and consequently to the entire Earth-system.

The uncertainties regarding the responses of plants to the changing environmental patterns resulted in a large part from the great challenge of unscramble the complex interactions between multiple direct impacts (photosynthesis, respiration, transpiration, phenology and nutritional aspects) and indirect impacts (drought, heat waves, fires, litter quality and decomposition and other environmental features) on plant physiology and ecology 
(SAXE et al., 2001; FOLEY et al., 2003). Key issues that need to be solved on this concern were: how and how much direct and indirect effects could affect the ability of plants to photosynthesize and use water and nutrients efficiently? Moreover, how these plant physiological and ecological processes, in turn, could amplify or suppress global changes by $\mathrm{CO}_{2}$ uptake and by favoring water and nutrient cycling? And finally, which methods should be used to study vegetation in the global change context? (SIMIONI et al., 2004; HULME, 2005; NIYOGI; XUE, 2006; KOSUGI et al., 2006; MENGE; FIELD, 2007; UNITED NATIONAUS ENVIRONMENTPROGRAMME - UNEP, 2009; BERRY et al., 2010; COATES et al., 2011; MALHI, 2012).

These questions have redirected plant physiological ecology to study key vegetation processes under the new environmental conditions instead of exploring plant mechanisms solely. Some examples are the great number of studies focused on the detection of photosynthesis responses to high $\mathrm{CO}_{2}$ concentrations (a direct impact) and to combinations of high $\mathrm{CO}_{2}$, high temperatures and droughts (direct and indirect impacts) (SAXE et al., 2001; LI et al., 2007; PINHEIRO; CHAVES, 2011).

Furthermore, these kinds of concerns have led plant physiologists to incorporate multidisciplinary perspectives to their experimental approaches. As with other branches of natural sciences, plant scientists have been impelled to work with integrative approaches across disciplines, across temporal and spatial scales, and across levels of organization, considering the complex interactions among the different themes related to the effects of global changes over vegetation (JARVIS, 1995; LAVOREL et al., 1999; AVISSAR, 2002; SIMS; GAMON, 2002; SOUZA; BUCKERIDGE, 2004; SMITH; WANDEL, 2006; ENQUIST et al., 2007; PINHEIRO; CHAVES, 2011).

In these perspectives, experimental studies have shown that direct effects of increasing $\mathrm{CO}_{2}$ concentrations can lead to short-term increase in photosynthetic rates. However, it is less clear whether direct effects of elevated $\mathrm{CO}_{2}$ could also result in increments of carbon assimilation at high hierarchical levels, because prolonged exposures often led to acclimation of some leaf traits, resulting in decreased functioning of the photosynthetic machinery. Downscaling to the Rubisco (Ribulose-1,5-bisphosphate Carboxylase/Oxygenase) transcripts level, it was demonstrated that plants exposed for a long period under high $\mathrm{CO}_{2}$ concentrations often present less Rubisco protein, and a general decline of photosynthesis. More complex discussions on the direct effects of $\mathrm{CO}_{2}$ concentrations from the leaf to the ecosystem physiology can be found in Kicklighter et al. (1999), Saxe et al. (2001),
Niyogi and Xue (2006), Trumbore (2006), Tjoelker and Zhou (2007), Li et al. (2007), Friend (2010), Raupach and Canadell (2010) and in Malhi (2012).

On the other side, some studies have shown that indirect impacts could affect vegetation functioning and structure in a more significant way, especially in the community level. Among such impacts, those caused by water and nutrient availability and high temperatures have been of first concern to natural and cultivated ecosystems (RAMBAL et al., 2003; ROSENZWEIG et al., 2004; LIN, 2007; HULME, 2005; HARPOLE et al., 2007; PINHEIRO; CHAVES, 2011). In conjunction with nitrogen and phosphorus availability, changes in the amount and timing of precipitation associated with new patterns of species composition in vegetated areas are expected to have particularly large impacts on the structure and function of many ecosystems (WINSLOW et al., 2003; SUTTLE et al., 2007; REICH et al., 2009; REICH et al., 2010; WRIGHT et al., 2011).

Due to the importance of water in limiting the physiological processes in all the biological levels of organization, it has been suggested that soil moisture mediates the influence of other factors affecting the functioning and structure of vegetation worldwide (as fires, light use efficiency, nutrient absorption and assimilation and high $\mathrm{CO}_{2}$ concentrations) (HARPOLE et al., 2007; PINHEIRO; CHAVES, 2011). In addition to the effects on gas and energy exchanges, some researchers have demonstrated that the variability in the supply of water can also affect vegetation processes through the effects of droughts on plant community composition and phenology. Changes in water availability can have strong effects on plant species numbers and relative abundance (POTTS et al., 2006; HARPOLE et al., 2007). If plants differ in their traits associated with water use, then changes in their relative abundance should affect whole-community processes as carbon sequestration, flowering, deciduousness and nutrient cycling. Because vegetation functioning depends strongly on moisture availability, changes in the precipitation regime or evapotranspiration rates could affect the patterns of plant growth and competition, modifying the structure and dynamic of ecosystems. Such changes should directly impact the carbon budget and the ability of ecosystems to use water and mineral nutrients efficiently.

As briefly exemplified, an exhausting number of studies with important environmental effects of global changes over vegetation functioning and structure at the leaf and canopy levels have been developed in the last decades. However, the great challenge in addition to 
elucidate mechanisms and processes affected by the modified environmental conditions is to incorporate the leaf level information into larger scales, and vice-versa. Some efforts were applied to solve this issue demonstrating that from leaf traits it was possible to determinate the main patterns defining community responses to environmental variability (JARVIS, 1995; REICHet al., 1999; NIINEMETS, 2001; RAMBAL et al., 2003; WRIGHT et al., 2005a; WRIGHT et al., 2005b; REICH et al., 2010; KOSUGI et al., 2006; WRIGHT et al., 2011).

The relations between leaf traits and community level responses have been used to verify plant strategies to grow and develop with limiting resources availability. Such information is essential to the calibration of dynamic biosphere-atmosphere models and vegetation remote sensing techniques. The incorporation of leaf level parameters into models allowed scaling from the leaf to the global level when simulating vegetation interactions and feedbacks with the environment (HULME, 2005; SIMS et al., 2006; MALHI, 2012). Remote sensing techniques also benefit from this information, leading to more accurate observation of vegetation (SIMS; GAMON, 2002; GRACE et al., 2007). However, the scaling exercise remains a significant challenge, since predictions of some ecosystems properties from leaf level information depends on the effects of global changes over large scale processes not strongly linked to the leaf traits. The scaling challenges will be discussed further in this review.

Another important aspect of plant physiological ecology studies in the context of the Earth-system was approaching plants as complex systems. As already mentioned, plant scientists have applied great efforts to understand the responses of vegetation in face of environmental adversity. This kind of approach allowed a better understand of responses of plants in relation to the environmental conditions, since it was possible to clearly observe the sensitivity and adaptation capacity of the main physiological processes to the occurrence of extreme climate episodes, higher atmospheric $\mathrm{CO}_{2}$ concentrations, depletion in soil fertility and water availability, soil salinization, desertification, recurrent forest fires, sea level raising, air pollution, heavy metals contamination, and all the broad implications of the loss of biodiversity (pollination, competition, herbivory and disease), amongst others (WATSON et al., 2000; SAXE et al., 2001; UNEP, 2002; HULME, 2005; CHARTZOULAKIS; PSARRAS, 2005; TJOELKER; ZHOU, 2007; UNEP 2009; COATES et al., 2011). Through this approach, the integration of scattered results observed at different space-time scales into consistent outputs could be done by the effective incorporation of powerful statistical, computational and modeling tools in order to elucidate contemporary plant physiological ecology issues.

\section{PLANTS AS COMPLEX SYSTEMS}

In the last decade some approaches have redirected plant physiological ecology to multidisciplinary studies. One significant output of this multidisciplinary interaction is the analysis of plants as complex systems. In fact, as all the living organisms, plants can be approached as complex systems because all its levels of organization undergo changes in time and space, are evolutionary and dynamic, non-linear, and may be particularly sensitive to external disturbances, which in turn reflect in their ability to modify and self-reorganize due to interactions with the environment (SOUZA; MANZATTO, 2000; EDELMAN; GALLY, 2001; SOUZA; BUCKERIDGE, 2004; SOUZA et al., 2009). This approach provides a better understanding of the dynamics of vegetation in all organizational levels, with new possibilities of observation and interpretation of biological data against environmental variations, especially because it is possible to derive system's characteristics, as sensitivity, adjustment capacity, resistance, exposure and vulnerability (CARPENTER et al., 2001; SOUZA; BUCKERIDGE, 2004; GALLOPÍN, 2006; SMITH; WANDEL, 2006).

The interactions of plants with the environment are very complex but can be organized in networks. Those networks are linked in a higher or smaller degree to the characteristics of their physical, chemical and biotic environment. Several physiological processes are involved on these networks that have the property to adjust in order to keep the plant or community stable in time and space. The adjustment processes are responsible for maintaining the properties that provide functional stability to an organism (e.g. its homeostatic balance), allowing it to deal with environmental variability (PRADO et al, 2004; SOUZA et al., 2009; PINHEIRO;CHAVES, 2011).

The number and strength of connections between elements in a network are strongly related to the stability of a system. In this way, stability is reported as the ability of the networks of a system to maintain the internal variations within a tolerance threshold or a variation range denominated homeostasis. The homeostasis of an organism is a reflection of its sensitivity, resistance, resilience, plasticity, connectivity and autonomy in relation to environmental variability. These characteristics can define the system's vulnerability to an environmental disturbance (EDELMAN; GALLY, 2001; SOUZA et al., 2005a, b). 
Contemporary definitions consider that vulnerability is the degree to which a system, sub-system or system component is susceptible to, or unable to cope with adverse effects such as harm due to exposure to a hazard, either a perturbation or stress. Although such a definition addresses environmental factors, it already includes some vegetation characteristics, such as susceptibility, which is a function of exposure, sensitivity, resilience and adaptive capacity or plasticity (CARPENTER et al., 2001; TURNER et al., 2003; GALLOPÍN, 2006; METZGER et al., 2006; SMITH; WANDEL, 2006; PIELKE JUNIOR et al., 2007)

It is important to notice that vulnerability is registered not only by exposure to perturbations and stresses, but also must include the capacity of the system to deal with variables of the human systems. From this perspective, the concept of sustainability emerged in the plant physiological ecology, linking in a diverse and complex way the dual objectives of meeting the needs of society while sustaining the life support processes of the ecosystems (CARPENTER et al., 2001; TURNER et al., 2003; GALLOPÍN, 2006). The sustainability and vulnerability themes enlarged, and redirected the focus on plant physiological ecology studies on two main axes: to understand the sensibility, resistance, plasticity, adjustment capacity and resilience of functional properties to environmental drivers, and to study the complex mechanisms that vegetation has to cope with and to adapt to stress situations, at diverse time-space scales.

The plant physiological ecology tools were used in both axes together with the complex system approaches to solve these issues. First: linking studies at the leaf level with remote sensing techniques and simulation modeling, in the up and downscaling procedures of functional processes. Second: coupling physiological and climate models to simulate landscape dynamics in diverse environmental scenarios. Third: evaluating potential risks and impacts as well as feedback responses of vegetation in the global change perspective through vulnerability assessments.

In this way, plant physiological studies with a complex system approach have been undertaken to define stability thresholds that can determine the vulnerability of vegetation to global changes in both, bottom-up and topdown approaches. The definition of threshold constrained by plant characteristics and environmental changes is essential information to be used to scale up ecosystem regulation from basic leaf-level processes. More details of this issue will be discussed in the next topic.

\section{THE SCALE CHANGING CHALLENGES}

\section{From leaf to the community to the ecosystem}

Some fundamental plant physiological and ecological processes have been neglected in early global changes studies. From the 1990's, an increasing attention has been given to those small scale processes related to impacts on agriculture and natural systems, due to the primary biological processes involved with the greenhouse gas emissions and its effects on atmosphere (SAXE et al., 2001; FOLEY et al., 2003; BERRY et al., 2010). From this point, it was recognized that photosynthesis, respiration and transpiration processes should be considered in all scales of organization in space and time: molecular to planetary and seconds to millennia approaches were important.

Unequivocally the primary process in this concern was photosynthesis, the complex metabolic pathway in which plants convert physicochemical into biochemical energy which is then used to reduce $\mathrm{CO}_{2}$ to carbohydrate. This process occurs majorly in green leaves and is responsible for plant growth, development and production. Some scientific efforts were applied to forecast the possible relations of photosynthetic metabolism (C3, C4 and CAM) in a warmer and $\mathrm{CO}_{2}$ richer world (KICKLIGHTER et al., 1999; SAXE et al., 2001; WINSLOW et al., 2003; TRUMBORE, 2006; LI et al., 2007; FRIEND, 2010; RAUPACH; CANADELL, 2010; FRIEND, 2010; MALHI, 2012). However, a great challenge is how to downscale the photosynthetic process from canopy to leaf level, and then go upward: upscaling from leaf to canopy, from canopy to community and from community to ecosystem.

The downscaling obstacles are related to the diverse types of photosynthetic metabolisms and the complex interplays and feedbacks related to environment and plasticity at the genotypic and phenotypic levels. Notwithstanding, there are attempts to model and represent photosynthetic reactions that could be useful to downscale photosynthesis to the molecular level from top-down approaches, as gas exchange measurements (POOLMAN; FELL, 2000; ENQUIST et al., 2003).

Some investigations also attempted to downscale leaf photosynthetic rate through global circulation models coupled with biosphere-atmosphere models (SELLERS et al., 1986; POTTER et al., 1998; LI et al., 2007), and others by remote sensing approaches (SIMS; GAMON, 2002; GRACE et al., 2007) with a less or greater degree of success. However, the effective incorporation of such small scale biophysical and biochemical mechanisms using large scale tools is still a crucial obstacle to be overcome to 
dynamically and spatial explicitly couple vegetation physiology and ecology in the global circulation models and in remote sensing approaches.

The physiological studies on the links between leaf traits and canopy physiology have been highly relevant to ecosystem modeling since they consider the effects of abiotic stress on the vegetation functioning. In general, the simulation models are square-grid representations, in a way that to each cell is assigned a set of typical properties, often including leaf traits such as specific leaf area, net carbon assimilation and water use efficiency. Due to this spatially-explicit implication, the use of leaf traits in models have shown to be a good alternative of upscaling physiological processes in both space and time (LAVOREL et al., 1999; DÍAZ et al., 1999; WRIGHT et al., 2005a, b).

At the leaf level, stomata are acknowledged for the control of assimilation, by restricting the supply of $\mathrm{CO}_{2}$ to photosynthetic metabolism (CHAVES et al., 2002; SIMIONI et al., 2004; PINHEIRO; CHAVES, 2011; MARTINS et al., 2012). Whereas other studies suggest that photosynthesis may be more directly limited by non-stomatal factors, particularly via a direct effect of stresses associated to high temperatures on the ATP synthase, thus leading to restricted photosynthetic rates by the ATP supply, as cited by Castrillo (1992) and Lawlor and Cornic (2002).

Some aspects of the control of stomata over leaf gas exchanges in the context of the Earth-system science was discussed by Berry et al. (2010). Since the stomata represent the link between water availability in the soil, plant and in atmosphere, it exerts a certain degree of control in whole plant physiological behavior. Because plant functioning depends strongly on the ability of stomata to control the water loss at the same time that the carbon assimilation happens, perturbations in this control at leaf level can impact the patterns of plant growth and production at the community level, directly impacting the carbon budget and the ability of ecosystems to use water and nutrient efficiently (JARVIS, 1995; CHAVES et al., 2002; MEDRANO et al., 2002; KOSUGI et al., 2006; POTTS et al., 2006; TRUMBORE, 2006; REICHet al., 2010).

These traits can be very similar among species and allow the definition of threshold values of stomata conductance from which the plants decrease the carbon assimilation and the transpiration, increasing the water and nutrient use efficiency and decreasing the vulnerability of the community and ecosystem to environmental variations. The definition of those vulnerability thresholds is important for the calibration of simulation models, to scale from leaf to stand level and to study the temporal and spatial dynamics of ecosystem functioning related to environmental variability (LAVORELet al., 1999; HULME, 2005; WRIGHT et al., 2005b; WRIGHT et al., 2011).

At the community level, it is well known that the plant response to environmental variability is complex but often leads to decrease in biomass accumulation and production due to a decrease in the leaf photosynthesis and increase in plant respiration (HUTLEY et al., 2001; RAMBAL et al., 2004; TRUMBORE, 2006; ICHII et al., 2007). Therefore, the understanding of the adjustments of stomata in water and carbon exchanges could be the starting point for the comprehension of the community responses to environmental variability.

The definition of the connections among dominant leaf traits and canopy physiology could be classified as a first order objective towards the prediction and simulation of ecosystem processes. Furthermore, given a certain scenario of environmental conditions, and assuming that those links are consistent, leaf traits may be used as a proxy for vulnerability predictions and ecosystem responses in time. In this context, the analysis of leaf traits together with canopy processes could be a useful empirical input to modeling water and carbon fluxes on a regional scale.

An approach with this point of view was successfully showed by Rambal et al. (2003). The procedure considered the functional relationships controlling mass and energy fluxes at the leaf and at the ecosystem level. Although such an approach was not mechanistic, because it did not link environmental factors with stomata functioning at the biochemical and biophysical levels, it explored the sensitivity of plants to environmental stresses. This characteristic is useful for the interpretation of field observations, prediction of both stomata conductance and gross assimilation at the ecosystem level, and to remote sense predictions of leaf traits.

With this consideration, a way to correlate plant physiology with whole canopy functioning is by the association of remote sensing of functional indices, (such as the normalized difference of vegetation index NDVI), and leaf traits. Confirming this, Grace et al. (2007) discussed that environmental stresses are responsible for changes in normal patterns of NDVI as a consequence of decrease in the greenness of leaves. For example, vegetation under water deficit show a decrease in reflectance in the nearinfrared bands, an increased red reflectance in the chlorophyll active band, and a consequent blue shift on the red edge (PEÑUELAS et al., 1997; SIMS; GAMMON, 2002; XIAO et al., 2005; SIMS et al., 2006; CHAMBERS et al., 2007; GRACE et al., 2007; ICHII et al., 2007).

Due to its characteristics, the NDVI could be useful to study the effects of environmental variability over leaf 
pigment content and thus link leaf physiology with the overall condition of the ecosystem, and correlate these variations to the capacity of the canopy to photosynthesize (NIYOGI; XUE, 2006; SIMS et al., 2006; GRACE et al., 2007). The LSWI (land surface water index), another remote sense vegetation index, has also been broadly used as a vegetation measure related to canopy and soil moisture condition. The LSWI can be indirectly related to carbon assimilation due to plant water status (HUETE et al., 2007).

However, predicting leaf traits from remotely sensed parameters, as well as predicting ecosystem behavior from leaf-scale traits, could be more complex. For example, Kosugi et al. (2006) observed some of the most important parameters for the evaluation of forest carbon uptake with a multi-layer analysis of leaf gas exchange and concluded that the variation in leaf stomatal and physiological attributes modify ecosystem-scale fluxes. However, the links between the leaf processes and the ecosystem processes were not well established in their work. These results confirmed that the processes at the leaf level are critical to influence ecosystem functioning, governing ecosystem carbon and water balance, but it also shows that there is not a direct relationship between leaf and ecosystem.

As expected, the correlations of variables from different sources and of different scales can simply give an insight about the influence of leaves on mass and energy fluxes of the integrated ecosystem. As an example, considering that LSWI and NDVI are consistent indices to measure vegetation functioning at ecosystem level, as well as the control of gas exchange by stomata conductance is a consistent pattern at the leaf level, the relationship between LSWI and stomata conductance or between NDVI and photosynthesis can be assessed just to infer about plant physiological status at leaf and canopy scales.

However, studies that analyze leaf trait information on a larger scale, such as canopy reflectance, have high relevance in the global change science since this kind of information greatly enhance the representations and simulations of different vegetation responses, including dynamic biological parameters of plant adjustments to environmental properties (WRIGHT et al., 2005a, b; WRIGHT et al., 2011). The improvement of these relationships can lead to deeper discussions about the potential effects of the global changes on the vegetation, since the up and downscaling of physiological processes are facilitated and threshold values of key leaf traits affecting ecosystems functioning can be defined (JARVIS, 1995; HURTT et al., 1998; RAMBALet al., 2003). However, these responses are particular to each ecosystem being both, site and species-specific (KOSUGI et al., 2006).
Therefore, the representations of the state of leaf-to-canopy functioning can be very particular, and more studies on these links are vital for improved descriptions, simulations and definition of stability thresholds of vegetation functioning under adverse environmental conditions.

\section{From ecosystem to the landscape}

By the end of the 1980s, increased attention to the structural and functional responses of ecosystems to the global changes has highlighted the need for quantitative approaches in order to analyze distribution and shape of land cover patches in the landscape, linking plant physiological and ecological processes at broad spatial and temporal scales (TURNER, 1989). At the landscape level, fragmentation pattern of land cover seemed to be a fundamental variable to the assessment of the many aspects of the ecosystem-human system vulnerability to global changes, since the patterns of change in land cover are regarded as a result of diverse interactions among land use politics and environmental drivers (LI, 2002; SOUTHWORTHet al., 2004).

As a consequence, a method for assessing continuous landscape fragmentation, based on fractal analysis was developed in the end of the 1980's (MILNE, 1988; MILNE, 1989). Fractal geometry incorporates complex system theory and applications in the study of landscape ecology on the basis of reducing information and assessing reliable generality in statistical space-time pattern of vegetation distribution (LI, 2002; THIELEN et al., 2008).

The concept of landscape fragmentation refers, in general, to the transformation of the land cover properties from a uniform to a more heterogeneous and patchy situation. The analysis of landscape fragmentation has been used frequently in the interpretation of the spatiotemporal patterns of land cover and land use changes, by calculating for each land cover class, a range of metrics to describe fragmentation and spatial distribution of ecosystems in the landscape (HARGIS et al., 1998; SOUTHWORTH et al., 2004). Because the landscape is a mosaic of objects, such as agricultural fields, urban areas, water bodies or natural vegetation patches, landscape fragmentation is often monitored using remote sensing, modeling and global information system tools (BALDÍ et al., 2006; THIELEN et al., 2008; GARRIGUES et al., 2008).

Analyses of changes in the land cover pattern obtained by using those tools generated information to correlations with environmental and anthropogenic disturbances, allowing the identification of the possible biophysical, biochemical and human processes driving the land cover changes. Within such relationship, the degree 
of landscape fragmentation could provide decisive information to derive ecosystems functioning, even if more details of all ecological processes affected within the landscape were unknown (SAUNDERS et al., 1991; SOUTHWORTH et al., 2004; BALDÍ et al., 2006).

Amongst some of the ecosystems processes affected by changes in the land cover pattern, generally three has primary concern on the physiological ecology aspect: i) alteration of the microclimate within and surrounding the patches; ii) the isolation of each area from other patches in the surrounding landscape; and iii) fire occurrence (SAUNDERS et al., 1991; BALDÍ et al., 2006; PACHA; PETIT, 2008). Thus, in a fragmented landscape there are changes in the physical and chemical environment as well as biogeographic changes. All patches are exposed to these effects to a greater or lesser degree, but they are all influenced by their size, shape, and position in the landscape (TURNER, 1989; SAUNDERS et al., 1991).

A large amount of discussions of landscape ecology have concentrated on the biogeographic aspects of vegetation, but the effects of fragmentation over the biophysical and biochemical processes have received little attention. Only a few studies mentioned that the fluxes of energy, momentum, carbon, water, and nutrients across the landscape are altered significantly as a result of changes in the land cover pattern (TURNER, 1989; SANTOS et al., 2003; HOFFMAN et al., 2003; SOUTHWORTH et al., 2004; CERNUSAK et al., 2006; GARRIGUES et al., 2008). However, it is well known that such changes have important consequences on mass and energy fluxes of both, natural and managed ecosystems at local and regional levels, since they are related to the occurrence of fires, alterations in wind speed and direction, albedo and runoff (SAUNDERS et al., 1991; BALDÍ et al., 2006; THIELEN et al., 2008).

Patterns of land cover change in most tropical developing countries are often driven by anthropogenic activity related to biomass burn in natural and agricultural ecosystems, deeply affecting the normal patterns of mass and energy exchange between vegetation and atmosphere. Although the natural ignitions are ecological components in tropical regions, especially in savanna areas, they are complex to define in terms of natural perturbations leading to changes in land cover, in biogeochemical cycles, and on vegetation composition across multiple spatial and temporal scales (BALDÍ et al., 2006; LANGNER et al., 2007; THIELEN et al., 2008). Besides the burn of biomass, another legacy of the landscape fragmentation in the tropics is the great diversity of ecosystem physiognomies. The land cover heterogeneity is dependent on soil types, water availability and altitude and also contributes to the high patchy landscape in the tropics. These are important factors conditioning the level of exposure and response of vegetation to the physical environment and determinate aspects of resistance and resilience of tropical ecosystems to perturbations.

Despite the important role of natural fire in the definition of functioning and structure of landscape, the history of technological advances, social and demographic changes as well as extreme episodes, and pressures upon natural resources has led to a point where fire regime could represent the most direct effect of humans on landscape. Recent studies hypothesize that fires might play a more important role than any other biophysical process in modifying the landscape dynamics at the regional level by three main causes: i) by resetting natural ecosystems to their early successional stages, ii) by favoring plant functional types adapted to recurrent disturbances, and iii) by changing the land cover structure, thus affecting energy, mass and momentum fluxes between land surface and atmosphere. Such modifications may have significant feedbacks on regional biosphere/atmosphere interactions (MOUILLOT et al., 2005; BOWMAN et al., 2009).

Interannual variability and seasonality of fires have been accurately related to climate and particularly to drought periods. In general, diverse studies have shown that shallow rooted grasslands get dry earlier in the dry season favoring high fire risk compared to the deep rooted forests, which can get access to water for a longer period. Concurrently, aerial biomass structure determines flammability with a higher fire risk for fine branches compared to thick trunks. As a consequence, grassland and shrublands fires are highly recurrent with low interannual variability, while severe forest fire happens only during prolonged droughts mostly driven by El Niño events in the tropical forests (THONICKE et al., 2001; MOUILLOT et al., 2002; BOND et al., 2005; MISTRY, 2005; MOUILLOT et al., 2005; BEERLING; OSBORNE, 2006; DI BELLA et al., 2006; BOWMAN et al., 2009).

Indeed, modeling current and future fire regime at the global scale has been based on available biomass and water status (THONICKE et al. 2001; BOWMAN et al., 2009). Beside this knowledge on climate influence on the fire regime, changes in fire occurrence in the last century clearly illustrate how land cover changes, changes in fire policies or forest management strategies can significantly affect long term changes in fire regime, and in a more significant manner than any other natural environmental trend (MOUILLOT et al., 2005).

Within such considerations, landscape structure and functioning has to be considered as a non-random 
process resulting from a complex interplay of environmental and social factors that constrains changes in land use and environmental characteristics. This way, fragmentation would be interrelated with fire frequency and microclimate variability, resulting in the loss of ecosystem services, abnormal mass, momentum and energy fluxes and loss of biodiversity (SANTOS et al., 2003; HOFFMAN et al., 2003; GRACE et al., 2006; KEITH et al., 2007; GONZALES et al., 2008; BOWMAN et al., 2009). These outputs of land use and land cover could result not only in modification of the carbon stocks in the landscape components, but also in feedback effect in atmospheric properties at regional scales (SANTOS et al., 2003; BOND et al., 2005; CERNUSAK et al., 2006), being essential in approaches aiming to understand causes and forecast impacts of the global changes over vegetation functioning and structure at diverse hierarchical levels.

\section{From landscape to the globe}

Unequivocally, the largely used tool to scale plant physiological ecology processes globally are the mechanistic spatial explicit models. These tools have been successfully used to perform simulations of the various forms of interaction among the physical, chemical and biological processes of vegetation within the environment over the last 20 years (RUNNING; GOWER, 1991; FEARNSIDE; FERRAZ, 1995; COSTA; FOLEY, 2000; COX et al., 2000; BONAN, 2008; MALHI, 2012).

Models in the scientific context, symbolize system components and their interrelationships to describe real phenomenon. There are many types of models, according to the objective and approach. Structural models represent patterns of a system in response to an environmental change (e.g., branching pattern of a canopy or root systems growth). Mechanistic models are able to simulate physicochemical and biological processes at different spatial and temporal scales considering adjustments and feedbacks of the system components to the environmental variables.

Studies with mechanistic models of biosphereatmosphere interaction with greater accuracy in representing the physiological and ecological processes of vegetation can describe with certain reliability the dynamics of Earth ecosystems. This is because the model can represent basic processes of plant physiology responding to large scale environmental variations at the mechanisms level, with great degrees of detail and complexity (RAMBAL et al., 2004; TRUMBORE, 2006).

The vegetation models can be grouped according to the processes involved into three categories: biogeochemical, biophysical and biogeographical. Examples are, respectively: CENTURY (PARTON et al., 1987), BGC (RUNNING; GOWER, 1991) and MET (RAICH et al., 1991); BATS (DICKINSON et al., 1984) and SiB (SELLERS et al., 1986); and BIOME(PRENTICE et al., 1992).

According to Costa and Yanagi (2006), mechanistic vegetation models were incorporated as components of climate models in the 1960's. Their main role was to provide a lower boundary condition (energy, mass and momentum fluxes) for the atmospheric models. At that time, vegetation was represented by a large number of aerodynamic formulations of energy exchange with coarse representations of albedo, infrared radiation balance and evapotranspiration without any approach of physiological processes (COSTA; YANAGI, 2006; BONAN, 2008). Since then, vegetation models have been evolving continuously over the last forty years, resulting in a more accurate representation of vegetation physiological and ecological processes in the regional to the global level (BONAN, 2008).

In the 1980 s the vegetation models included the effects of ecosystems on the energy and water fluxes. As examples of models of this generation the most known are BATS -Biosphere Atmosphere Transfer Scheme (DICKINSON et al., 1986) and SiB - Simple Biosphere Model (SELLERS et al., 1986). These models were able to represent the canopy explicitly, including processes of radiative and turbulent transfer above and within canopy, physical and biological controls of evapotranspiration, and the influence of vegetation on the hydrological cycle. Following, the third generation of vegetation models was developed in the 1990s. As part of those models the plant physiological and ecological processes were incorporated through a good representation of the stomata control of transpiration and of the biochemistry of photosynthesis (BONAN, 2008).

Currently, vegetation models have evolved to the point accuracy in the simulations of the carbon cycle and vegetation structure and dynamics (FOLEY et al., 1996; BONAN, 2008; MALHI, 2012). In the modern models, the soil, atmosphere and biosphere form a coupled system where the weather influences vegetation functioning, structure and biogeography, which in turn feedback soil and atmospheric processes. Some models also include changes in land use, since there is a large need to evaluate the impact of these changes in vegetation functioning, as discussed before.

In general, these last generation models provide more realistic leaf to canopy responses to environmental variability, and are therefore powerful tools to study 
responses of vegetation in the context of the global changes. There are many examples of vegetation models of this fourth generation, among them IBIS (FOLEY et al., 1996), FOREST-BGC and BIOME-BGC (RUNNING; GOWER, 1991), INTEC (CHEN et al., 2000), SITE (SANTOS; COSTA, 2004), CenW (KIRSCHBAUM, 1999), and BEPS (LIU et al., 2002).

The use of vegetation models with a plant physiological ecology approach is an important tool in understanding the role that vegetation, and consequently ecosystems, plays on the global stocks and fluxes of carbon, water, nutrients and energy, integrating spatially explicit information over hours to decades. This type of study would hardly be performed without the use of modeling techniques. Additionally, the type of information provided by models is useful to support the development of actions aiming at stabilizing vegetation facing environmental threats, maximizing ecosystem service and minimizing direct and indirect environmental impacts on most vulnerable ecosystems. This would allow the prediction of ecosystems structure and functioning in the future, supplying basic information necessary to the establishment of mitigation strategies to withstand the negative impacts forecasted with the ongoing environmental trends.

\section{TOWARDS A MORE PLANT PHYSIOLOGICAL ECOLOGY IN THE EARTH-SYSTEM SCIENCE}

The present-to-near future challenge of plant physiologists and ecologists in the global changes perspectives is not only to know that global changes are able to affect vegetation, but rather to consider the physiological and biophysical thresholds of vegetation to those changes. This vulnerability approach would be helpful to enlarge the knowledge about the role that vegetation plays in the Earth-system, and also would be helpful to the establishment of mitigation strategies to withstand the negative impacts and feedbacks of vegetation on the context of the Earth-systems processes.

In order to overcome this challenge, research on plant physiology in the Earth-system must be performed including all the aspects related to landscape ecology, anthropogenic activities, fire regime, and other relevant large scale processes. This could be approached by the association of experimental studies with field observations, remote sensing techniques and by simulations with process-based, mechanistic and spatially explicit models.

For now, analysis of plant physiological, structural and ecological data performed in a complex system viewpoint seems to be the best way to aggregate responses obtained at different levels and observe the whole picture of the interactions between vegetation and the environment. More studies have to be performed within such perspective allowing the observation of the sensitivity and adaptation capacity of plants to the altering biotic, physical and chemical environment. This knowledge is important because the responses of vegetation to global changes can be expected to vary among ecosystems in both, magnitude and intensity, depending on the properties of the dominant species and because mitigation and adaptation strategies depend on vulnerability assessments.

However, as diverse types of impacts of global changes over vegetated systems are recognized and the interactions between local, regional, and global scales becomes more documented, skillful forecasts of the ecosystems responses and vulnerability becomes an increasingly challenging task. This challenge will require a greater focus on the assessment and incorporation of the social and biotical variables on the analysis, since impacts on vegetation extend far beyond mass and energy trades into the soil-vegetation-atmosphere, and other perturbations, such as land use changes and ecological interactions can have important effects on plant ecophysiological processes.

For example, considering the biotical aspect, the interaction among species (plant-plant, plant-insect and plant-microorganisms) is poorly understood in the context of the Earth-system science although it may play important roles in shaping the ecophysiological responses to environmental variability, determining allocation patterns, resistance and resilience to stresses. For this reason factors such as dispersal ability and competition capacity for nutrients and water, defense against insect herbivory and plant diseases, and symbiosis with micorhizal or rizobium will need to be mechanistically implemented and coupled with functional properties in future modeling approaches. This task needs to be performed based on experimental data.

Another important consideration within the possibilities assessed in the present analysis is the changing picture of land use, and its interactions with ecosystems functioning and fire occurrence. This is a more difficult issue to be implemented, since it depends on anthropogenic pressures. Such variables are clearly important and will certainly define the fine-scale limitations on the functional patterns of natural and managed ecosystems on the landscape. One approach to assess and include the social component in the future studies is to question the community about their current knowledge and reaction to effects due to impacts of the existing environmental conditions, and this way determine the 
threshold of vegetation to potential human pressures based in political and economical scenarios.

Further, it is needed to better develop our understanding of how information on the leaf, canopy, ecosystem and globe might be used together in scaling exercises to generate long-term predictions, based on relative sensitivity, adaptation capacity, and vulnerability to global changes. We also need improved models of the temporal and spatial responses of physiological processes to environment, because it is increasingly clear that longterm responses to environmental variability may differ greatly among plant functional types and possible feedback on the atmosphere is still uncertain. For the construction of such models, a broader array of experiments in contrasting ecosystem types into the regional landscape is needed; including both whole system manipulations and more focused experimental treatments at the leaf level. Also needed is the long-term monitoring through the development of research networks that will allow spatial extrapolation and validation of predictions based on intensive experimental studies.

Clearly, our review presents some possibilities of comparison and prediction of vegetation responses to environment in a bottom-up perspective, representing only a-part-of-the-whole in the Earth-system science. For now, its main applications are: i) the statement of the complexity of the vegetation responses at diverse scales; ii) the need for integrative approaches to study the effects of global changes that is not just multidisciplinary, but truly interdisciplinary; iii) the establishment of the main connections between physiological processes; iv) to know the limitations and to point out the necessity of the subsequent studies and, finally, v) as a reminder of the major constraints on long-term predictions based on relatively small-area and short-term studies. We think this knowledge is an important component of the strategy to understand, simulate, anticipate and, finally, set up strategies to mitigate and/or adapt the potential effects of global changes on vegetation.

\section{ACKNOWLEDGMENTS}

The authors wish to thank the Conselho Nacional de Desenvolvimento Científico e Tecnológico (CNPq), the Fundação de Amparo à Pesquisa do Estado de Minas Gerais (FAPEMIG), the Coordenação de Aperfeiçoamento de Pessoal de Nível Superior (CAPES) and the European Community's Seventh Framework Programme (FP7/20072013) under Grant Agreement No 212492 (CLARIS LPB. A Europe-South America Network for Climate Change Assessment and Impact Studies in La Plata Basin) for financial support.

\section{REFERENCES}

AVISSAR, R. Preface to special issue on the large-scale biosphere-a tmosphere experiment in Amazonia (LBA). Journal of Geophysical Research, Washington, v. 107, n. D20, p. 1-2, Oct. 2002.

\section{BALDÍ, G.; GUERSCHMAN, J. P.; PARUELO, J. M.} Characterizing fragmentation in temperate South America grasslands. Agriculture, Ecosystems and Environment, Amsterdam, v. 116, n. 3-4, p. 197-208, Sept. 2006.

BEERLING, D. J.; OSBORNE, C. P. The origin of the savanna biome. Global Change Biology, Oxford, v. 12, n. 11, p. 2023-2031, Nov. 2006.

BERRY, J.A.; BEERLING, D.J.; FRANKS, P.J. Stomata: key players in the earth system, past and present. Current Opinion in Plant Biology, Amsterdam, v. 13, n. 3, p. 233-240, Jun. 2010.

BONAN, G.B. Forests and climate change: forcings, feedbacks, and climate benefits of forests. Science, Washington, v. 320, n. 5882, p. 1444-1449, Jun 2008.

BOND, W. J.; WOODWARD, F. I.; MIDGLEY, G. F. The global distribution of ecosystems in a world without fire. New Phytologist, Oxford, v.165, n. 2, p. 525-538, Feb. 2005.

BOWMAN, D.M.J.S. et al. Fire in the Earth system. Science, New York, v. 324, n. 5926, p. 481-484, Apr. 2009.

CARPENTER, S. et al. From metaphor to measurement: resilience of what to what? Ecosystems, Berlin, v. 4, n. 8, p. 765-781, Dec. 2001.

CASTRILLO, M. Sucrose metabolism in bean plants under water deficit. Journal of Experimental Botany, Oxford, v. 43, n. 12, p. 1557-1561, Dec. 1992.

CERNUSAK, L. A. et al. Stem and leaf gas exchange and their responses to fire in a north Australian tropical savanna. Plant, Cell and Environment, Washington, v. 29, n. 4, p. 632-646, Apr. 2006.

CHAMBERS, J. Q.et al. Regional ecosystem structure and function: ecological insights from remote sensing of tropical forests. Trends in Ecology and Evolution, Amsterdam, v. 22, n. 9, p. 415-423, Sept. 2007. 
CHARTZOULAKIS, K.; PSARRAS, G. Global change effects on crop photosynthesis and production in Mediterranean: the case of Crete, Greece. Agriculture, Ecosystems and Environment, Amsterdam, v. 106, n. 2-3, p.147-157, Apr. 2005.

CHAVES, M. M. et al. How plants cope with stress in field. Photosynthesis and growth. Annals of Botany, Oxford, v.89, n. 7, p. 907 -916, June 2002.

CHEN, W.; CHEN, J.M.; CIHLAR, J. An integrated terrestrial ecosystem carbon-budget model based on changes in disturbance, climate, and atmospheric chemistry. Ecological Modelling, London, v. 135, n. 2-3, p. 55-79, Dec. 2000.

COATES, J.C.; MOODY, L.A.; SAIDI, Y. Plants and the earth system - past events and future challenges. New Phytologist, Oxford, v. 189, n. 2, p. 370-373, Jan. 2011.

COSTA, M.H.; YANAGI, S.N.M. Effects of Amazon deforestation on the regional climate - Historical perspective, current and future research. Revista Brasileira de Meteorologia, Rio de Janeiro, v. 21, n. 3a, p. 200-211, Dec. 2006.

COSTA, M.H; FOLEY, J.A Combined effects of deforestation and doubled atmospheric $\mathrm{CO}_{2}$ Concentrations on the climate of Amazonia. Journal of Climate, Boston, v.13, n.1, p.18-34, Jan. 2000.

COSTANZA, R. et al. The value of the world's ecosystem services and natural capital. Nature, London, v. 387, n. 6630, p. 253-260, May 1997.

COX, P.M. et al. Acceleration of global warming due to carbon-cycle feedbacks in a coupled climate model. Nature, London, v. 408, p. 184-187, Nov. 2000.

CRAMER, W. et al. Global response of terrestrial ecosystem structure and function to $\mathrm{CO}_{2}$ and climate change: results from six dynamic global vegetation models. Global Change Biology, Oxford, v. 7, n. 4, p. 357-373, Apr. 2001.

CRUTZEN P.J. Geology of mankind. Nature, London, v.415, n. 23, Jan. 2002. 23p.

CRUTZEN P.J.; STEFFEN W. How long have we been in the Anthropocene era? Climatic Change, Berlin, v. 61, n. 3, p. 251-257, Dec. 2003.
DAVIDSON, E.; ARTAXO, P. Globally significant changes in biological processes of the Amazon Basin: results of the Large-scale Biosphere-Atmosphere Experiment. Global Change Biology, Oxford, v.10, n. 5, p. 519-529, May 2004.

DI BELLA, C. M. et al. Continental fire density patterns in South America. Global Ecology and Biogeography, Washington, v. 15, n. 2, p. 192-199, Mar. 2006.

DÍAZ, S.et al. Plant functional traits, ecosystem structure and land-use history along a climate gradient in central-western Argentina. Journal of Vegetation Science, Uppsala, v.10, n. 5, p. 651-660, Oct. 1999.

DICKINSON, R. E. et al. Biosphere-Atmosphere transfer scheme (BATS) for the NCAR community climate model NCAR Technical note TN-275+STR. Boulder: National Center for Atmospheric Research, 1984. 69p.

DICKINSON, R et al. Biosphere-Atmosphere Transfer Scheme (BATS) for the NCAR community climate model. NCAR Technical note TN-275-STR. Boulder: National Center for Atmospheric Research, 1986. 69p.

EDELMAN, G.M; GALLY, J.A. Degeneracy and complexity in biological systems. Proceedings of the National Academy of Sciences of the United States of America, Stanford, v. 98, n. 4, p. 13763-68, Nov. 2001.

ENQUIST, B.J. et al. Scaling metabolism from organisms to ecosystems. Nature, London, v. 423, n. 6940, p. 639642, June 2003.

FEARNSIDE, P. M.; FERRAZ, J. A Conservation gap analysis of Brazil's Amazonian vegetation. Conservation Biology, Washington, v.9, n. 5, p.1134-1147, Oct. 1995.

FOLEY, J. A. et al. Green surprise? How terrestrial ecosystems could affect earth's climate. Frontiers in Ecology and the Environment, Washington, v. 1, n. 1, p. 38-44, Feb. 2003.

FOLEY, J.A. et al. An integrated biosphere model of land surface processes, terrestrial carbon balance and vegetation dynamics. Global Biogeochemical Cycles, Washington, v. 10, n. 4, p.603-628, Dec.1996.

FRIEND, A.D. Terrestrial plant production and climate change. Journal of Experimental Botany, Oxford, v. 61, n. 5, p.1293-1309, Mar. 2010. 
GALLOPÍN, G. C. Linkages between vulnerability, resilience, and adaptive capacity. Global

Environmental Change, Amsterdam, v. 16, n.3, p. 293303, Aug. 2006.

GARRIGUES, S.; ALLARD, D.; BARET, F. Modeling temporal changes in surface spatial heterogeneity over an agricultural site. Remote Sensing of Environment, New York, v. 112, p. 588-602, Feb. 2008.

GONZALES, J. R.; DELBARRIO, G;; DUGUY, B. Assessing functional landscape connectivity for disturbance propagation on regional scales - A cost-surface model approach applied to surface fire spread. Ecological Modelling, London, v. 211, n. 1-2, p. 121-141, Feb. 2008.

GRACE, J. et al. Can we measure terrestrial photosynthesis from space directly, using spectral reflectance and fluorescence? Global Change Biology, Oxford, v. 13, n. 7, p. 1484-1497, July 2007.

GRACE, J. et al. Productivity and carbon fluxes of tropical savannas. Journal of Biogeography, Oxford, v. 33, n. 3, p.387-400, Mar. 2006.

HARGIS, C. D.; BISSONETTE, J. A.; DAVID, J. L. The behavior of landscape metrics commonly used in the study of habitat fragmentation. Landscape Ecology, Dordrecht, v. 13, n. 3, p. 167-186, June 1998.

HARPOLE, W. S.; POTTS, D. L.; SUDING, K. N. Ecosystem responses to water and nitrogen amendment in a California grassland. Global Change Biology, Oxford, v. 13, n. 11, p. 2341-2348, Nov. 2007.

HOFFMANN, W. A.; ORTHEN, B.; NASCIMENTO, P. K. V. Comparative fire ecology of tropical savanna and forest trees. Functional Ecology, Oxford, v. 17, n. 6, p. 720-726, Dec. 2003.

HULME, P. E. Adapting to climate change: is there scope for ecological management in the face of a global threat? Journal of Applied Ecology, Cambridge, v. 42, n. 5, p. 784 -794 , Oct. 2005.

HURTT, G. C. et al. Terrestrial models and global change: challenges for the future. Global Change Biology, Oxford, v. 4, n.5, p. 581 - 590, June 1998.
HUTLEY, L. B.; O’GRADY, A. P.; EAMUS, D. Monsoonal influences on evapotranspiration of savanna vegetation of northern Australia. Oecologia, New York, v. 126, n. 3, p. 434-443, Feb. 2001.

ICHII, K. et al. Constraining rooting depths in tropical rainforests using satellite data and ecosystem modeling for accurate simulation of gross primary production seasonality. Global Change Biology, Oxford, v. 13, n. 1, p. 67-77, Jan. 2007.

JACKSON, L.E. et al. Case study on potential agricultural responses to climate change in a California landscape. Climatic Change, Berlin, v. 109 supplement 1, p. 407-427, Dec. 2011.

JARVIS, P. G. Scaling processes and problems. Plant, Cell and Environment, Oxford, v. 18, n. 10, p. 1079-1089, Oct. 1995.

KEITH, D.A.et al. Plant functional types can predict decade-scale changes in fire-prone vegetation. Journal of Ecology, Oxford, v. 95, n.6, p. 1324-1337, Nov. 2007.

KICKLIGHTER, D. W. et al. A firt-order analysis of the potential role of $\mathrm{CO}_{2}$ fertilization to affect the global carbon budget: a comparizon of four terrestrial biosphere models. Tellus, Copenhagen, v. 51, n. 2, p. 343-366, Apr. 1999.

KIRSCHBAUM, M.U.F. CEN, W, a forest growth model with linked carbon, energy, nutrient and water cycles.

Ecological Modelling, London, v. 118, n. 1, p. 1-94, June 1999.

KOSUGI, Y. et al. Impact of leaf physiology on gas exchange in a Japanese evergreen broad-leaved forest.

Agricultural and Forest Meteorology, Amsterdam, v. 139, n. 3-4, p. 182-199, Oct. 2006.

LANGNER, A.; MIETTINEN, J.; SIEGERT, F. Land cover change 2002-2005 in Borneo and the role of fire derived from MODIS imagery. Global Change Biology, Oxford, v. 13, n. 11, p. 2329-2340, Nov. 2007.

LAVOREL, S.; McINTYRE, S.; GRIGULIS, K. Plant response to disturbance in a Mediterranean grassland: How many functional groups? Journal of Vegetation Science, Uppsala, v. 10, n. 5, p. 661-672, Oct. 1999. 
LAWLOR, D. W.; CORNIC, G. Photosynthetic carbon assimilation and associated metabolism in relation to water deficits in higher plants. Plant, Cell and

Environment, Oxford, v. 25, n. 2, p. 275-294, Feb. 2002.

LI, C. Estimation of fire frequency and fire cycle: a computational perspective. Ecological Modelling, London, v. 154, n. 1-2, p. 103-120, Aug. 2002.

LI, P.; BOHNERT, H. J.; GRENE, R. All about FACE plants in a high- $\left[\mathrm{CO}_{2}\right]$ world. Trends in Plant Science, London, v. 12, n. 3, p.87-89, Mar. 2007.

LIN, B. B. Agroforestry management as an adaptive strategy against potential microclimate extremes in coffee agriculture. Agricultural and Forest Meteorology, Amsterdam, v. 144, n. 1-2, p. 85-94, May 2007.

LIU, J. et al. Net primary productivity mapped for Canada at $1 \mathrm{~km}$ resolution. Global Ecology and Biogeography, Oxford, v. 11, n. 2, p. 115-129, Mar. 2002.

MALHI, Y. The productivity, metabolism and carbon cycle of tropical forest vegetation. Journal of Ecology, Oxford, v. 100, n. 1, p. 65-75, Jan. 2012.

MARTINS, G.A. et al. Stomatal density distribution patterns in leaves of the Jatobá (Hymenaea courbaril L.). Tress Structure and Function, Berlin, v. 26, n. 2, p. 571-579, Apr. 2012.

MEDRANO, H. et al. Regulation of photosynthesis of $\mathrm{C}_{3}$ plants in response to progressive drought: stomatal conductance as a reference parameter. Annals of Botany, London, v. 89, p. 895-905, June 2002. Special.

MENGE, D.N. L.; FIELD, C.B. Simulated global changes alter phosphorus demand in annual grassland. Global Change Biology, Oxford, v. 13, n. 12, p. 2582-2591, Dec. 2007.

METZGER, M. J. et al. The vulnerability of ecosystem services to land use change. Agriculture, Ecosystems and Environment, Amsterdam, v. 114, n. 1, p. 69-85, May 2006.

MILNE, B.T. Heterogeneity as a multi-scale characteristic of landscapes. In: KOLOSA, J.; PICKETT, S.T.A. (Eds.). Ecological heterogeneity. New York: Springer-Verlag,p. 69-84, 1989.
MILNE, B.T. Measuring the fractal dimension of landscapes. Applied Mathematics and Computation, Washington, v. 27, n. 1, p. 67-79, July, 1988.

MISTRY, J. Assessing fire potential in a Brazilian savanna nature reserve. Biotropica, St. Louis, v. 37, n. 3, p. 439-451, Sept. 2005.

MOUILLOT, F.; FIELD, C. B. Fire history and the global carbon budget: a $1^{\circ} \times 1^{\circ}$ fire history reconstruction for the 20th century. Global Change Biology, Oxford, v. 11, n. 3, p. 398-420, Mar. 2005.

MOUILLOT, F.; RAMBAL, S.; JOFFRE, R.; Simulating climate change impacts on fire frequency and vegetation dynamics in a Mediterranean-type ecosystem. Global Change Biology, Oxford, v. 8, n. 5, p. 423-437, May 2002.

NIINEMETS, U. Global-scale climatic controls of leaf dry mass per area, density, and thickness in trees and shrubs. Ecology, Washington, v. 82, n. 2, p. 453-469, Feb. 2001.

NIYOGI, D.; XUE, Y. Soil moisture regulates the biological response of elevated atmospheric $\mathrm{CO}_{2}$ concentrations in a coupled atmosphere-biosphere model. Global and Planetary Change, Amsterdam, v. 54, n. 1-2, p. 94-108, Nov. 2006.

PACHA, M.J.; PETIT S. The effect of landscape structure and habitat quality on the occurrence of Geranium sylvaticum in fragmented hay meadows. Agriculture, Ecosystems and Environment, Amsterdam, v. 123, n. 1-3, p.81-87, Jan. 2008.

PARTON, W.J. et al. Analysis of factors controlling soil organic matter levels in great plains grasslands. Soil Science Society of America Journal, Madison, v.51, n. 5, p.1173-1179, May, 1987.

PEÑUELAS, J. et al. Photochemical reflectance index and leaf photosynthetic radiation-use-efficiency assessment in Mediterranean trees. International Journal of Remote Sensing, London, v. 18, n. 13, p. 2863-2868, Sept. 1997.

PIELKE JR, R. A. et al. A new paradigm for assessing the role of agriculture in the climate system and in climate change. Agricultural and Forest Meteorology, Amsterdam, v. 142, n. 2-4, p. 234-254, Feb. 2007. 
PINHEIRO, C.; CHAVES, M.M. Photosynthesis and drought: can we make metabolic connections from available data? Journal of Experimental Botany, Oxford, v. 62, n. 3, p. 869-882, Nov. 2011.

POTTER, C. S. et al. Regional application of an ecosystem production model for studies of biogeochemistry in Brazilian Amazonia. Global Change Biology, Oxford, v. 4, n. 3, p. 315-333, Mar. 1998.

POOLMAN, M.G; FELL, D.A. Modelling photosynthesis and its control. Journal of Experimental Botany, Oxford, v. 51, n. 343 supplement 1, p. 319-328, Feb. 2000.

POTTS, D. L. et al. Antecedent moisture and seasonal precipitation influence the response of canopy-scale carbon and water exchange to rainfall pulses in a semiarid grassland. New Phytologist, Oxford, v. 170, n. 4, p. 849-860, 2006.

PRADO, C. H. B. A. et al. Seasonal leaf gas exchange and water potential in a woody cerrado species community. Brazilian Journal of Plant Physiology, Londrina, v. 16, n. 1, p. 7-16, Jan.-Apr. 2004.

PRENTICE, I. C. et al. Special Paper: A global biome model based on plant physiology and dominance, soil properties and climate. Journal of Biogeography, Oxford, v. 19, n. 2, p.117-134, Mar. 1992.

RAICH, J. W. et al. Potential net primary productivity in South America: application of a global model. Ecological Applications, Ithaca, v. 1, n. 4, p.399-429, Nov. 1991.

RAMBAL, S.et al. The growth respiration component in eddy CO2 flux from a Quercus ilex mediterranean forest.

Global Change Biology, Oxford, v. 10, n. 9, p. 1460 - 1469, Sept. 2004.

RAMBAL, S.et al. Drought controls over conductance and assimilation of a Mediterranean evergreen ecosystem: scaling from leaf to canopy. Global Change Biology, Oxford, v. 9, n. 12, p. 1813 1824, Dec. 2003.

RAUPACH, M. R.; CANADELL, J. G. Carboln and the Anthropocene. Current Opinion in Environmental Sustainability, Oxford, v. 2, n. 4, p. 210-218, Oct. 2010 .
REICH, P. B.; TURNER, D. P.;BOLSTAD, A. P. An approach to spatially distributed modeling of net primary production (NPP) at the landscape scale and its in validation of EOS NPP products. Remote Sensing of Environment, New York, v. 70, n. 1, p. 69-81, Oct. 1999.

REICH, P.B.; OLEKSYN, J.; WRIGHT, I.J. Leaf phosphorus influences the photosynthesis-nitrogen relation: a cross-biome analysis of 314 species. Oecologia, New York, v. 160, n. 2, p. 207-212, May 2009.

REICH, P.B. et al. Evidence of a general 2/3-power law of scaling leaf nitrogen to phosphorus among major plant groups and biomes. Proceedings of the of The Royal Society B: Biological Sciences, London, v. 277, n. 1683, p. 877-883, Mar. 2010.

ROCKSTRÖM, J. et al. A safe operating space for humanity. Nature, London, v. 461, p. 472-475, Sept. 2009.

ROSENZWEIG, C. et al. Water resources for agriculture in a changing climate: international case studies. Global Environmental Change, Oxford, v. 14, n. 4, p. 345-360, Dec. 2004.

RUNNING, S.W; GOWER, S.T. Forest-BGC, a general model of forest ecosystem processes for regional applications. II. Dynamic carbon allocation and nitrogen budgets. Tree Physiology, Oxford, v. 9, n. 1-2, p.147-160, Jul.-Sep. 1991.

SANTOS, A. J. B.et al. Effects of fire on surface carbon, energy and water vapour fluxes over campo sujo savanna in central Brazil. Functional Ecology, Oxford, v. 17, n. 6, p. 711-719, Dec. 2003.

SANTOS, S. N. M.; COSTA, M. H. A simple tropical ecosystem model of carbon, water and energy fluxes. Ecological Modelling, London, v. 176, p. 291-312, Sept. 2004.

SAUNDERS, D. A.; HOBBS, R. J.; MARGULES, C. R. Biological consequences of ecosystem fragmentation: a review. Conservation Biology, Cambridge, v. 5, n. 1, p. 18-32, Mar. 1991.

SAXE, $\mathrm{H}$. et al. Tree and forest functioning in response to global warming. New Phytologist, Oxford, v. 149, n. 3, p. 369-400, Mar. 2001. 
SELLERS, P. J. et al. A simple biosphere model ( $\mathrm{SiB}$ ) for use with general circulation models. Journal of the Atmospheric Sciences, Boston, v. 43, n. 6, p.505-531, Mar. 1986.

SIMIONI, G. et al. Leaf gas exchange characteristics and water- and nitrogen-use efficiencies of dominant grass and tree species in a West African savanna. Plant Ecology, Dordrecht, v. 173, n. 2, p. 233 - 246, Aug. 2004.

SIMS D. A.; GAMON, J. A. Relationships between leaf pigment content and spectral reflectance across a wide range of species, leaf structures and developmental stages. Remote Sensing of Environment, New York, v. 81, n. 2-3, p. 337-354, Aug. 2002.

SIMS, D. A. et al. Parallel adjustments in vegetation greenness and ecosystem $\mathrm{CO}_{2}$ exchange in response to drought in a Southern California chaparral ecosystem. Remote Sensing of the Environment, New York, v. 103, n. 3, p. 289-303, Aug. 2006.

SMITH, B.; WANDEL, J. Adaptation, adaptive capacity and vulnerability. Global Environmental Change, Oxford, v. 16, n. 2, p. 282-292, May 2006.

\section{SOUTHWORTH, J.; MUNROE, D.; NAGENDRA, H.} Land cover change and landscape fragmentationcomparing the utility of continuous and discrete analyses for a western Honduras region. Agriculture, Ecosystems and Environment, Amsterdam, v. 101, n. 2-3, p. 185-205, Feb. 2004.

SOUZA, G.M.; BUCKERIDGE, M.S. Sistemas complexos: novas formas de ver a Botânica. Revista Brasileira de Botânica, São Paulo, v. 27, n. 3, p. 407419, jul.-set. 2004.

SOUZA, G.M.; MANZATTO, A.G. Hierarquia autoorganizada em sistemas biológicos. In: D’OTTAVIANO, I.M.L.; GONZALES, M.E.Q. (Eds.). Auto organização: estudos interdisciplinares. Campinas: CLE/UNICAMP, p. 153-173, 2000.

SOUZA, G.M.; PINCUS, S.M.; MONTEIRO, J.A.F. The complexity stability hypothesis in plant gas exchange under water deûcit. Brazilian Journal of Plant Physiology, Campos dos Goytacazes, v.17, n. 4, p. 363373, Oct.-Dec. 2005a.
SOUZA, G.M. et al. Using network connectance and autonomy analyses to uncover patterns of photosynthetic responses in tropical woody species. Ecological Complexity, Amsterdam, v. 6, n. 1, p. 15-26, Mar. 2009.

SOUZA,G.M. et al. Network connectance and autonomy analyses of the photosynthetic apparatus in tropical tree species from different successional groups under contrasting irradiance conditions. Revista Brasileira de Botânica, São Paulo, v. 28, n.1, p. 47-59, Jan.-Mar 2005b.

SUTTLE, K. B.; THOMSEN, M. A.; POWER, M. E. Species interactions reverse grassland responses to changing climate. Science, Washington, v. 315, n. 5872, p. 640-642, Feb. 2007.

THIELEN, D. R. et al. Assessment of land use changes on woody cover and landscape fragmentation in the Orinoco savannas using fractal distributions. Ecological Indicators, Amsterdam, v. 8, n. 3, p. 224-238, May 2008.

THONICKE, K. et al. The role of fire disturbance for global vegetation dynamics: coupling fire into a Dynamic Global Vegetation Model. Global Ecology \& Biogeography, Oxford, v. 10, n. 6, p. 661-677, Nov. 2001.

TJOELKER, M. G.; ZHOU, X. The many faces of climate warming. New Phytologist, Cambridge, v. 176, n. 4, p. 739-742, Dec. 2007.

TRUMBORE, S. Carbon respired by terrestrial ecosystems - recent progress and challenges. Global Change Biology, Oxford, v. 12, n. 2, p. 141-153, Feb. 2006.

TURNER, B. L. et al. Illustrating the coupled humanenvironment system for vulnerability analysis: Three case studies. Proceedings of the national Academy of Science of the United States of America, Washington, v. 100, n. 14, p. 8080-8085, July 2003.

TURNER, M.G. Landscape Ecology: the effects of patterns and process. Annual Review of Ecology and Systematics, Palo Alto, v. 20, p. 171-197, Nov. 1989.

UNITED NATIONS ENVIRONMENT PROGRAMME UNEP. UNEPYear Book: New Science and Developments in our Changing Environment. Nairobi, 2009. 
UNITED NATIONS ENVIRONMENTPROGRAMME UNEP. GEO-3: Global Environmental Outlook Report 3. London, 2002.

WALTHER, G. R.; POST, E.; CONVEY, P. Ecological responses to recent climate change. Nature, London, v. 416, n. 6879, p. 389-395, Mar. 2002.

WATSON, R. T. et al. (Ed.). Land use, Land use change and Forestry: a special report of the Intergovernmental Panel on Climate Change (IPCC). Cambridge: Cambridge University, 2000.

WINSLOW, J.C.; HUNT JR., E.R.; PIPER, S.C. The influence of seasonal water availability on global C3 versus $\mathrm{C} 4$ grassland biomass and its implications for climate change research. Ecological Modelling, London, v. 163, n. 1-2, p. 153-173, May 2003.
WRIGHT, I. J. et al. Assessing the generality of global leaf trait relationships. New Phytologist, Cambridge, v. 166, n. 2, p. 485-496, May 2005a.

WRIGHT, I. J. et al. Modulation of leaf economic traits and trait relationships by climate. Global Ecology and Biogeography, Oxford, v. 14, n. 5, p. 411-421, Sept. 2005b.

WRIGHT, S J. et al. Potassium, phosphorus, or nitrogen limit root allocation, tree growth, or litter production in a lowland tropical forest. Ecology, Ithaca, v. 92, n. 8, p. 1616-1625, Aug. 2011.

XIAO, X. M. et al. Modeling gross primary production of an evergreen needleleaf forest using MODIS and climate data. Ecological Applications, Washington, v.15, n. 3, p. 954-969, June 2005. 